\title{
Demographic Disparities in the Districts of Assam, A Composite Index Analysis
}

\author{
Barindra Das \\ Research Scholar, Department of Economics, Dibrugarh University
}

\begin{abstract}
The paper intends to study the demographic disparities among the districts of Assam. The disparities are studied with some certain demographic parameters such as male population, female population, rural population, urban population, sex ratio, literacy rate etc. The data used for the study are from secondary sources such as mainly census publications, Economic survey reports, government publications of Directorate of Economics and Statistics etc based on the recent census. Econometrics tools are being used to study the district disparity. The main objectives of the study are to study the demographic disparities in the districts of Assam and to study the Sex wise disparities in the districts of Assam. There are wide disparities among the districts of Assam relating to demographic development. Similarly disparities have been found in respect of sex wise development. So briefly we can conclude that in the districts of Assam it was found a wide spread gap between the highest score of composite index and the lowest score of composite index.
\end{abstract}

Keywords: Demography, District, Disparity, Composite Index etc.

\section{Introduction}

The development of all the regions of a country is never uniform whether the country is developed or under developed. (Adhyapok P.K. and Ahmed A.R.). As per 2011 census, total population of Assam was $31,169,272$. The total population of the state has increased from $26,638,407$ to $31,169,272$ in the last ten years with a growth rate of $16.93 \%$ (online Assam 2012.). Of the 27 districts of Assam, eight districts registered rise in the decadal population growth rate. Religious minority-dominated districts like Dhubri, Goalpara, Barpeta, Morigaon, Nagaon, Hailakandi etc. recorded growth rates ranging from 20 per cent to 24 per cent during the last decade. On the other hand, eastern Assam districts like Sivasagar, Jorhat etc. registered around 9 per cent population growth, and for the record, these districts do not share any international border (cdpsindia).

In 2011, literacy rate in the state was $73.18 \%$. Male literacy rate was $78.81 \%$ and female literacy rate was $67.27 \%$. In 2001, the census had recorded literacy in Assam at $63.3 \%$ with male literacy at $71.3 \%$ and female at $54.6 \%$. Urbanization rate was recorded at $12.9 \%$ (Director of Census Operations, Census of India 2001)

The state of Assam has 27 districts (including 4 new districts of BTAD) with Kamrup (Rural and Metropolitan) district being the most populous accounting $8.92 \%$ to total population of the state. The population density is highest in the Nagaon district having 604 persons per sq.km. whereas in the North Cachar Hills population density is only 38 persons per sq.km. The literacy rate is highest in Jorhat district (77.91\%) and is lowest in Dhubri district (49.86\%). (Census 2001)

It is true that wide district disparity is still a hard reality in Assam particularly in demographic development. In this paper attempt has made to study the demographic disparities among the districts of Assam. The disparities are studied with some certain demographic parameters such as male population, female population, rural population, urban population, sex ratio, literacy rate etc.

\section{Objectives}

(I) To study the demographic disparities in the districts of Assam.

(II) To study the Sex wise disparities in the districts of Assam.

\section{Hypothesis}

There is no any demographic development disparity between Male and Female in the districts of Assam.

\section{Developmental Indicators}

Development is a multidimensional process and its impact cannot be fully captured by a single indicator. A number of indicators when analyzed individually do not provide an integrated and easily comprehensible picture of reality. Hence, there is a need for building up of a composite index of development based on optimum combination of all the indicators. Each district faces situational factors of development unique to it as well as common administrative and financial factors. (Narain P. and et. al. 2009). Developmental 
indicators common to all the districts have been included in the analysis. Composite indices of development have been obtained for different districts by using the data on the following developmental indicators.

\begin{tabular}{|c|c|}
\hline 1 & 2 \\
\hline Index & Indicators used for the construction of the indices for 2012 \\
\hline DDIOM & $\begin{array}{ll}- & \mathrm{X}_{1}-\text { Total Population of Male(in Lakh) } \\
\text { - } & \mathrm{X}_{2}-\text { Total Population of Rural Male(in lakh) } \\
\text { - } & \mathrm{X}_{3}-\text { Total Population of Urban Male (in 10,000) } \\
\text { - } & \mathrm{X}_{4}-\% \text { of Total Male Population decadal growth } \\
\text { - } & \mathrm{X}_{5}-\% \text { of Total Rural Male Population decadal growth } \\
\text { - } & \mathrm{X}_{6}-\% \text { of Total Urban Male Population decadal growth } \\
& \mathrm{X}_{7} \text { - Literacy Rate of Male Population }\end{array}$ \\
\hline DDIOF & $\begin{array}{ll}\text { - } & \mathrm{X}_{8^{-}} \text {Total Female Population (in Lakh) } \\
\text { - } & \mathrm{X}_{9}-\text { Total Rural Female Population (in lakh) } \\
& \mathrm{X}_{10}-\text { Total Urban Female Population (in 10.000) } \\
\text { - } & \mathrm{X}_{11^{-}} \% \text { of Female decadal growth } \\
\text { - } & \mathrm{X}_{12^{-}} \% \text { of Rural Female decadal growth } \\
\text { - } & \mathrm{X}_{13^{-}} \% \text { of Urban Female decadal growth } \\
& \mathrm{X}_{14^{-}} \text {Female Literacy Rate }\end{array}$ \\
\hline
\end{tabular}

N.B. - DDIM-Demographic Development Indicators of Male

DDIF-Demographic Development Indicators of Female

\section{Methodology}

The study is on the Demographic Disparities in the Districts of Assam, and is based on secondary data pertaining to the demographic variables of the different districts. The time reference period of the study is 2012 . Main sources of data are Census of India publications, SRS as well as statistical department publications, Government publications, Directorate of Economics and Statistics, Published reports, research papers, journals, articles, different web sources etc. Composite indices have been prepared for ranking the different districts of the state.

\section{Materials and Methods}

The following methods are used for preparing the research paper.

\section{Composite index of development and developmental distances between different Districts}

The crucial issue of regional disparity analysis lies in the construction of a Composite Index out of the several indicators chosen for the purpose. All the selected indicators are to be converted in to a common base either by rank ordering or indexing and finally they are to be converted in to a single index of overall development.

Let a set of $\mathrm{n}$ points represent districts $1,2 \ldots \mathrm{n}$ for a group of indicators $1,2 \ldots \mathrm{k}$, which can be represented by a matrix $\left(X_{i j}\right) ; \mathrm{i}=1,2, \ldots \mathrm{n}$ and $\mathrm{j}=1,2, \ldots \mathrm{k}$. As the developmental indicators included in the analysis are in different units of measurement and since our object is to arrive at a single composite index relating to the dimension in question. There is a need for standardized as shown below:

Where, $S_{j}^{2}=\frac{\sum_{i=1}^{n}\left(X_{i j}-\bar{X}_{j}\right)^{2}}{n}$ and

$$
Z_{i j}=\frac{X_{i j}-\bar{X}_{j}}{S_{j}}
$$

$$
\bar{X}_{j}=\left(\sum_{i=1}^{n} \frac{X_{i j}}{n}\right)
$$

$(\mathrm{i}=1,2 \ldots \mathrm{n}),(\mathrm{j}=1,2, \ldots, \mathrm{k})$

Let $\left|Z_{i j}\right|$ denotes the matrix of standardized indicators. The best district for each indicator (with maximum/minimum standardized value depending upon the direction of the indicator) is identified and from this the deviations of the value for each district has been taken for all indicators in the following manner:

$C_{i}=\left(\sum_{j=1}^{k}\left(Z_{i j}-Z_{o j}\right)^{2}\right)^{1 / 2}$,

where $\boldsymbol{Z}_{\boldsymbol{o} \boldsymbol{j}}$ is the standardized value of the jth indicator of the best district and $\boldsymbol{C}_{\boldsymbol{i}}$ denotes the pattern of development of ith district.

The composite index of development is obtained through the following formula:

$$
D_{i}=\frac{C_{i}}{C}
$$


$C=\bar{C}+2 S$,

$$
\bar{C}=\sum_{i=1}^{n} \frac{C_{i}}{n}
$$

And

$$
S=\left(\sum_{i=1}^{n} \frac{\left(C_{i}-\bar{C}\right)^{2}}{n}\right)^{1 / 2}
$$

\section{Results and Discussion}

Composite indices of demographic development have been worked out for different districts of Assam. The districts have been ranked on the basis of developmental indices. The composite indices of development along with the rank of the districts are presented in Table-1.

\begin{tabular}{|c|c|c|c|c|c|}
\hline \multirow[t]{2}{*}{ Sl. No. } & \multirow[t]{2}{*}{ Districts } & \multicolumn{2}{|l|}{ Male } & \multicolumn{2}{|l|}{ Female } \\
\hline & & $\mathrm{CI}$ & Rank & $\mathrm{CI}$ & Rank \\
\hline 01 & Kokrajhar & 1.493 & 27 & 0.253 & 13 \\
\hline 02 & Dhubri & 0.393 & 21 & 1.843 & 25 \\
\hline 03 & Goalpara & 0.056 & 12 & 0.903 & 22 \\
\hline 04 & Barpeta & 0.022 & 9 & 0.754 & 21 \\
\hline 05 & Marigaon & 0.008 & 7 & 0.904 & 23 \\
\hline 06 & Nagaon & 0.273 & 18 & 2.513 & 27 \\
\hline 07 & Sonitpur & 0.626 & 24 & 0.467 & 19 \\
\hline 08 & Lakhimpur & 0.006 & 6 & 0.055 & 9 \\
\hline 09 & Dhemaji & 0.001 & 3 & 2.158 & 26 \\
\hline 10 & Tinsukia & 0.002 & 4 & 0.088 & 11 \\
\hline 11 & Dibrugarh & 0.025 & 10 & 0.007 & 4 \\
\hline 12 & Sibsagar & 0.161 & 15 & 0.024 & 7 \\
\hline 13 & Jorhat & 0.3 & 19 & 0.079 & 10 \\
\hline 14 & Golaghat & 0.081 & 14 & 0.022 & 6 \\
\hline 15 & Karbi Anglong & 0.021 & 8 & 0.002 & 3 \\
\hline 16 & Dima Hasao & 0.52 & 23 & 0.017 & 5 \\
\hline 17 & Cachar & 0.339 & 20 & 0.431 & 17 \\
\hline 18 & Karimganj & 0.057 & 13 & 0.347 & 16 \\
\hline 19 & Hailakandi & 0.002 & 5 & 0.311 & 15 \\
\hline 20 & Bongaigaon & 0.000196 & 2 & 0.0008 & 2 \\
\hline 21 & Chirang & 0.639 & 25 & 0.0002 & 1 \\
\hline 22 & Kamrup(R) & 0.186 & 16 & 0.46 & 18 \\
\hline 23 & Kamrup (M) & 0.188 & 17 & 1.556 & 24 \\
\hline 24 & Nalbari & 0.00007 & 1 & 0.291 & 14 \\
\hline 25 & Baksa & 0.049 & 11 & 0.144 & 12 \\
\hline 26 & Darrang & 0.662 & 26 & 0.688 & 20 \\
\hline 27 & Udalguri & 0.487 & 22 & 0.052 & 8 \\
\hline
\end{tabular}

Table 1: Ranking of the districts on the basis of gender

\section{Main Findings}

(i) The computed values of Composite index of demographic development for male shows that Nalbari stands first followed by Bongaigaon, while Kokrajhar stands last in the rankings.

(ii) Similarly composite index for female shows that Chirang standa first followed by Bongaigaon, while Nagaon stands last in the rankings.

(iii) Kokrajhar, Sonitpur, Dibrugarh, Sivasagar, Jorhat, Golahhat, Karbi-Anglong, Dima Hasao, Darrang, these nine districts have biased towards men in demographic development in comparison to Female.

(iv) Interestingly Only Bongaigaon remains the same Rank both Male and female as compared to their CI.

(v) Remaining all other districts have biased towards female in respect of demographic development.

(vi) Chirang have a drastic favorable difference of female development in respect of male as it stands first rank of female as against twenty fifth in case of female.

(vii) Similarly Dhemaji stands twenty sixth positions in female demographic development as against third position in male which is shows drastic unfavorable development towards female.

\begin{tabular}{|c|c|c|c|c|}
\hline \multicolumn{5}{|l|}{ Correlations } \\
\hline & & & VAR00001 & VAR00002 \\
\hline Spearman's rho & VAR00001 & Correlation Coefficient & 1.000 & .039 \\
\hline
\end{tabular}

\section{Hypothesis Testing}




\begin{tabular}{|l|l|l|l|l|}
\hline \multirow{4}{*}{} & Sig. (2-tailed) &. & .847 \\
\cline { 3 - 5 } & $\mathrm{N}$ & 27 & 27 \\
\cline { 2 - 5 } & \multirow{4}{*}{ VAR00002 } & Correlation Coefficient & .039 & 1.000 \\
\cline { 3 - 5 } & Sig. (2-tailed) & .847 &. \\
\cline { 3 - 5 } & $\mathrm{N}$ & 27 & 27 \\
\hline
\end{tabular}

This low value (0.039) shows that the correlation between Male demographic development and Female demographic development is very low,

\begin{tabular}{|c|c|c|c|c|c|c|}
\hline \multicolumn{7}{|c|}{ One-Sample Test } \\
\hline & \multicolumn{6}{|c|}{ Test Value $=0$} \\
\hline & \multirow[t]{2}{*}{$\mathrm{t}$} & \multirow[t]{2}{*}{$\mathrm{df}$} & \multirow[t]{2}{*}{ Sig. (2-tailed) } & \multirow[t]{2}{*}{ Mean Difference } & \multicolumn{2}{|c|}{$\begin{array}{l}\text { 95\% Confidence Interval } \\
\text { of the Difference }\end{array}$} \\
\hline & & & & & Lower & Upper \\
\hline VAR00001 & 9.165 & 26 & .000 & 14.00000 & 10.8601 & 17.1399 \\
\hline VAR00002 & 9.165 & 26 & .000 & 14.00000 & 10.8601 & 17.1399 \\
\hline
\end{tabular}

$\mathrm{T}$ table value at $5 \%$ level of significance and 26 degrees of freedom 1.706

Since the calculated value of t-statistics in case of rank correlation for both the cases (i.e. 9.0165) is greater than the $t$ table value (1.706) which is lies under the rejection region. Therefore our null hypothesis is rejected. So we can conclude that there is a gap between demographic development of Male and demographic development of female.

\section{Conclusions}

From the study it can be concluded that the state Assam has a wide range of disparity in respect of demographic indicators both within and among the districts. Though few districts able to attain better ranks in comparison to others districts but still there intra district gender disparity is remarkable. So Policy maker should keep concentration of both the factors while they prepare any demographic policy.

It should be also worth mentioning here that though the study is trying to analyze the disparities among the districts of Assam in respect of demographic development, so many indicators still remaining out of our purview. Further the study is static in nature which is based only on one time period. So wide spread opportunities are there in the field for further research which may cover more and more indicators.

\section{References}

[1]. Adhyapok P. K. and Ahmed A. R. (2012), "Disparity of Infrastructure in Assam: An Inter-District study", Indian Journal of Regional Science, Vol. 34, No. 2012.

[2]. Aisha Ghaus A. F. and et al (1996), "Social Development Ranking Of Districts of Pakistan" The Pakistan Development Review, Vol. 35, No. 4, Papers And Proceedings PART IIT Wealth Annual General Meeting Of The Pakistan Society Of Development Economists Islamabad, December 14-16, 1996 (Winter 1996), Pp. 593-614Published By: Pakistan Institute Of Development Economics, Islamabad

[3]. Narain P. and et al (2009); "Inter-District Variation of Socio-Economic Development in Andhra Pradesh" Journal Of The Indian Society Of Agricultural Statistics 63(1), 2009 New Delhi Pp 35-42).

[4]. Nath A. (2007), "Inter District Disparities in Health Care Service of Assam", Associate Proff., Dept. of Statistics T.H.B. College, Jamugurihat 2007, email -anath@ rediffmail.com

[5]. Raychaudhuri A. and Haldar S.K. (2009); "An Investigation into The Inter-District Disparity in West Bengal, 1991-2005", Economic \& Political Weekly EPW June 27, 2009 Vol Xliv Nos 26 \& 27 Pp263.

[6]. Subhash C. K., (2003) "Workforce diversity status: a study of employees' reactions", Industrial Management \& Data Systems, Vol. 103 Issue: 4, pp.215 - 226).

[7]. Government of Assam Census 2011. "Onlineassam". Retrieved 6 June 2012.)

[8]. cdpsindia. "centre for development and peace studies")

[9]. Government of Assam 2002-03. "Statistics of Assam". Archived from the original on 7 June 2007. Retrieved 3 June 2007.). 